\title{
Inseminasi Buatan Berbasis Semen Beku Sexing-Sperm Guna Memperbaiki Kinerja Reproduksi Sapi dan Biogas Sebagai Sumber Energi Alternatif di Desa Kuripan Karangawen Demak
}

\author{
Achmad Buchori, Mega Novita, Dian Ayu Azhari \\ Universitas PGRI Semarang, Indonesia \\ achmadbuchori@upgris.ac.id
}

Received: $12^{\text {th }}$ October $2020 \mid$ Accepted: $29^{\text {th }}$ November $2020 \mid$ Published: $30^{\text {th }}$ January 2021

Key word:

Dissemination;

artificial

insemination;

sexing-sperm;

biogas;

organic fertilizer

Kata Kunci

Diseminasi,

inseminasi

buatan;

sexing-sperm;

biogas;

pupuk organik

\section{Abstract}

Kuripan is a village in Karangawen District, Demak Regency, Central Java Province, Indonesia. Based on the source of statistical data for Kuripan Village, Karangawen District, Demak Regency in 2019, people who are in the lower economy are quite high, at about 40\%. Basically Kuripan Village has good potential in the livestock sector. The majority of Kuripan Village residents raise beef cattle which fill the Central Java market, around $214,830 \mathrm{Kg}$ per year. Even so, they have not been able to optimize their potential to improve the welfare of their citizens. Through a program of dissemination of appropriate technology products, artificial insemination based on sexing-sperm frozen semen and a digester that produces biogas and organic fertilizers were applied in Kuripan Village. The community development method used in this work makes the community both as the subject and as the object. The result of this activity is an increase in the knowledge and motivation of the residents which ultimately increases their income.

\section{Abstrak}

Kuripan adalah sebuah desa di Kecamatan Karangawen, Kabupaten Demak, Provinsi Jawa Tengah, Indonesia. Berdasarkan sumber data statistik Desa Kuripan, Kecamatan Karangawen Kabupaten Demak tahun 2019, masyarakat yang berada pada ekonomi bawah terbilang cukup tinggi yaitu sebanyak $40 \%$. Pada dasarnya Desa Kuripan memiliki potensi yang baik sektor peternakan. Masyarakat Desa Kuripan mayoritas beternak sapi potong yang memenuhi pasar Jawa Tengah sekitar $214.830 \mathrm{Kg}$ per tahun. Meskipun demikian, mereka belum mampu mengoptimalkan potensinya untuk meningkatkan kesejahteraan hidup warganya. Melalui program diseminasi produk teknologi tepat guna, inseminasi buatan berbasis semen beku sexing-sperm dan digester penghasil biogas dan pupuk organikditerapkan di Desa Kuripan. Metode yang digunakan adalah community development yang menjadikan masyarakat sebagai subjek sekaligus objek dalam kegiatan ini. Hasil dari kegiatan ini adalah meningkatnya pengetahuan dan motivasi warga yang akhirnya meningkatkan pendapatannya. 


\section{PENDAHULUAN}

Kuripan adalah sebuah desa di Kecamatan Karangawen, Kabupaten Demak, Provinsi Jawa Tengah, Indonesia. Terletak di jalan raya Semarang Purwodadi Km 2.5 dengan $7^{\circ} 01^{\prime} 46.1$ "LS 110³3'34.6"BT. Di sebelah utara dan timur, Desa Kuripan berbatasan dengan Desa Bumirejo. Sedangkan di sebelah selatan betatasan dengan Desa Karangawen dn Kecamatan Mranggen sampai di bagian barat. Wilayah Desa Kuripan terbagi atas 4 dusun, yaitu Dusun Kuripan, Dusun Panjen. Dusun Sengor dan Dusun Sumengko. Peta Desa Kuripan, Kecamatan Karangawen Kabupaten Demak ditunjukkan pada Gambar 1.

Berdasarkan sumber data statistik Desa Kuripan, Kecamatan Karangawen Kabupaten Demak tahun 2019, anak yang sekolah TK/sederajat sebanyak 172 orang, Tamat SD/sederajat sebanyak 140 orang, Tamat SMP/ sederajat sebanyak 1010 orang, Tamat SMA sebanyak 206 orang dan Perguruan Tinggi sebanyak 68 orang. Mayoritas penduduk Desa Kuripan berprofesi sebagai petani/ buruh tani yaitu sebanyak 844 orang. Warga yang berdagang sebanyak 128 orang, PNS sebanyak 30 orang dan yang beternak sebanyak 30 orang.

Kondisi ekonomi penduduk di Desa Kuripan, Kecamatan Karangawen Kabupaten Demak dikelompokkan dalam tiga tingkatan, yaitu golongan ekonomi bawah sebanyak $40 \%$, menengah sebanyak $35 \%$, dan golongan atas sebanyak $25 \%$. Data tersebut menunjukkan bahwa mayoritas masyarakat Desa Kuripan, Kecamatan Karangawen Kabupaten Demak tergolong tidak mampu.

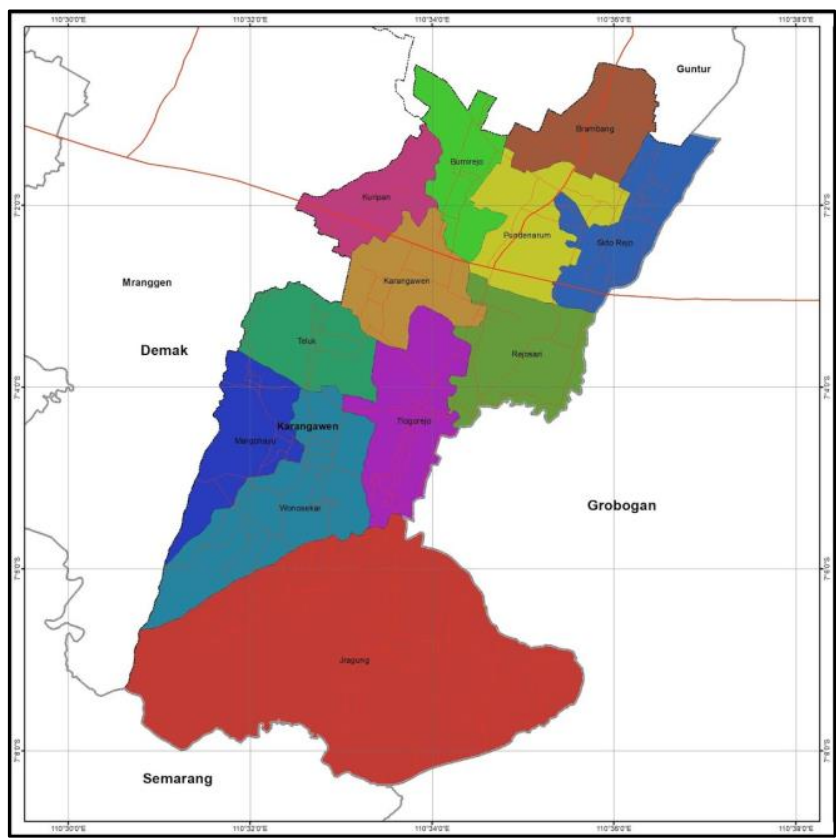

Gambar 1. Peta Desa Kuripan, Kecamatan Karangawen Kabupaten Demak 
Pada dasarnya, Desa Kuripan memiliki beberapa potensi seperti pengembangan pertanian, peternakan dan industri. Di sector pertanian, Desa Kuripan merupakan salah satu sentra padi, tembakau, dan jagung. Sedangkan di sektor peternakan, masyarakat Desa Kuripan mayoritas beternak sapi potong yang memenuhi pasar Jawa Tengah sekitar $214.830 \mathrm{Kg}$ per tahun. Untuk sektor industri, Desa Kuripan memiliki letak yang strategis menghubungkan Kota Semarang dan Purwodadi. Namun, potensi tersebut belum dimanfaatkan secara maksimal untuk meningkatkan kesejahteraan warganya. Terutama di bidang peternakan sapi yang sering mengalami kendala sulit bunting meskipun sudah dilakukan Inseminasi Buatan (IB) atau kawin suntik berulangkali.

Biasanya, untuk berhasil membuat sapi bunting para peternak harus melakukan IB sebanyak tiga kali, bahkan ada beberapa sapi yang lebih dari itu. Setiap IB dilakukan, peternak mengundang petugas peternakan di wilayah setempat. Selain permasalahan tersebut, masyarakat Desa Kuripan, Kecamatan Karangawen Kabupaten Demak juga belum mampu memanfaatkan limbah peternakan sapi secara optimal. Limbah tersebut berupa limbah padat berupa feces/kotoran ternak dan sisa pakan; dan limbah cair berupa air limbah pencucian kandang, air limbah sanitasi ternak dan air kencing sapi.

Berdasarkan latar belakang di atas, melalui program diseminasi teknologi tepa guna beberapa solusi ditawarkan untuk peningkatan kesejahteraan masyarakat Desa Kuripan, Kecamatan Karangawen Kabupaten Demak terutapa di bidang peternakan sapi. Pertama untuk meningkatkan sapi bunting, inseminasi buatan berbasis semen beku sexing-sperm akan diterapkan. Pelatihan peningkatan kinerja reproduksi akan diberikan kepada para peternak sapi. Kedua, untuk memanfaatkan limbah ternak sapi secara optimal, digester biogas akan dibangun menyesuaikan dengan kondisi geografis lingkungan di sekitar peternakan sapi.

Hasil akhir digester ini berupa biogas yang merupakan sumber energy alternatif pengganti Liquified Petroleum Gas (LPG) dan juga pupuk prganik yang dapat dimanfaatkan untuk menunjang sector pertanian. Pelatihan penggunaan reactor biogas dan mekanisme pengolahan limbah ternak sapi menjadi biogas juga akan diberikan untuk meningkatkan kesadaran warga dalam merawat digester tersebut. Dengan kedua solusi yang ditawarkan, warga Desa Kuripan, Kecamatan Karangawen Kabupaten Demak diharapkan memiliki pendapatan yang meningkat dan kesejahteraannya semakin baik. 


\section{METODE}

Sasaran utama pada program diseminasi produk teknologi ke masyarakat adalah kelompok tani yang ada di Desa Kuripan, Kecamatan Karangawen Kabupaten Demak yaitu Gawe Santoso, Krido Sekti, Makaryo dan Kismo Husodo. Pendekatan yang digunakan dalam program diseminasi teknologi tepa guna ini adalah Community Development (Phillips \& Pittman, 2014). Metode ini merupakan pendekatan yang berorientasi kepada upayaupaya pengembangan pemberdayaan masyarakat dengan menjadikan masyarakat sebagai subyek dan sekaligus obyek pembangunan dan melibatkan mereka secara langsung dalam berbagai kegiatan pengabdian masyarakat sebagai upaya meningkatkan peran serta mereka dalam pembangunan demi kepentingan mereka sendiri.

Tahapan dalam kegiatan ini dilakukan dengan (1) identifikasi kebutuhan masyarakat, (2) perancangan, pembuatan, (4) pendampingan operasional. Pertama tahap identifikasi kebutuhan masyarakat, wawancara dan observasi langsung dilakukan kepada mitra. Kedua, tahap perancangan dilakukan dengan cara studi literatur dan diskusi. Tahap ketiga, pembuatan, dilakukan dengan cara sosialisasi, praktek secara langsung dan diskusi. Terakhir adalah pendampingan yang dilakukan dengan metode praktek mandiri dan tanya jawab secara langsung. Kegiatan diseminasi teknologi tepat guna ini dilaksanakan selama 8 bulan

\section{HASIL DAN PEMBAHASAN}

Inseminasi Buatan (IB) berbasis semen

\section{beku sexing sperm}

Inseminasi Buatan (IB) pada sapi atau yang biasa dikenal dengan istilah kawin suntik adalah suatu cara atau teknik untuk memasukkan mani (spermatozoa atau semen) yang telah dicairkan dan telah diproses terlebih dahulu yang berasal dari ternak jantan ke dalam saluran alat kelamin betina dengan menggunakan metode dan alat khusus yang disebut 'insemination gun' (Salisbury dkk., 1978; Susilawati, 2013). Pertama kali diperkenalkan di Indonesia pada awal tahun 1950-an oleh Prof. B. Seit dari Denmark di Fakultas Hewan dan Lembaga Penelitian Peternakan Bogor. Inseminasi buatan ini merupakan langkah yang tepat untuk meningkatkan populasi ternak sapi secara cepat dan tepat. Beberapa keuntungan yang didapatkan dari teknologi IB ini adalah (1) menghemat biaya pemeliharaan ternak jantan, (2) dapat mengatur jarak kelahiran ternak dengan baik, (3) mencegah terjadinya kawin sedarah pada sapi betina (inbreeding), (4) masa penyimpanan sperma dapat lebih lama dengan bantuan peralatan dan teknologi 
yang baik serta semen beku masih dapat dipakai untuk beberapa tahun kemudian walaupun pejantan telah mati, menghindari kecelakaan yang sering terjadi pada saat perkawinan karena fisik pejantan terlalu besar, dan (6) menghindari ternak dari penularan penyakit terutama penyakit yang ditularkan dengan hubungan kelamin.

Salah satu faktor utama yang menjadi penentu kusuksesan IB adalah kecermatan dalam mendeteksi birahi yang biasanya terjadi pada malam hari. Pada saat birahi, liang leher rahim (servix) sapi berada pada posisi terbuka. IB yang dilakukan pada turun menjadi $75 \%$. Prosentasi tersebut semakin menurun, jika IB dilakukan 6 jam sesudah birahi 62,5\%, 12 jam sesudah birahi $32,5 \%, 18$ jam sesudah birahi $28 \%$ dan 24 jam sesudah birahi menjadi hanya $12 \%$ (Kusumawati, 2018). Oleh karena itu petani diharapkan dapat memonitor kejadian birahi dengan baik dengan cara mencatat siklus birahi semua sapi betinanya (dara dan dewasa). Salah satu cara yang sederhana dan murah untuk membantu petani untuk mendeteksi birahi, adalah dengan memberi cat di atas ekor, bila sapi betina minta kawin (birahi) cat akan kotor / pudar / menghilang

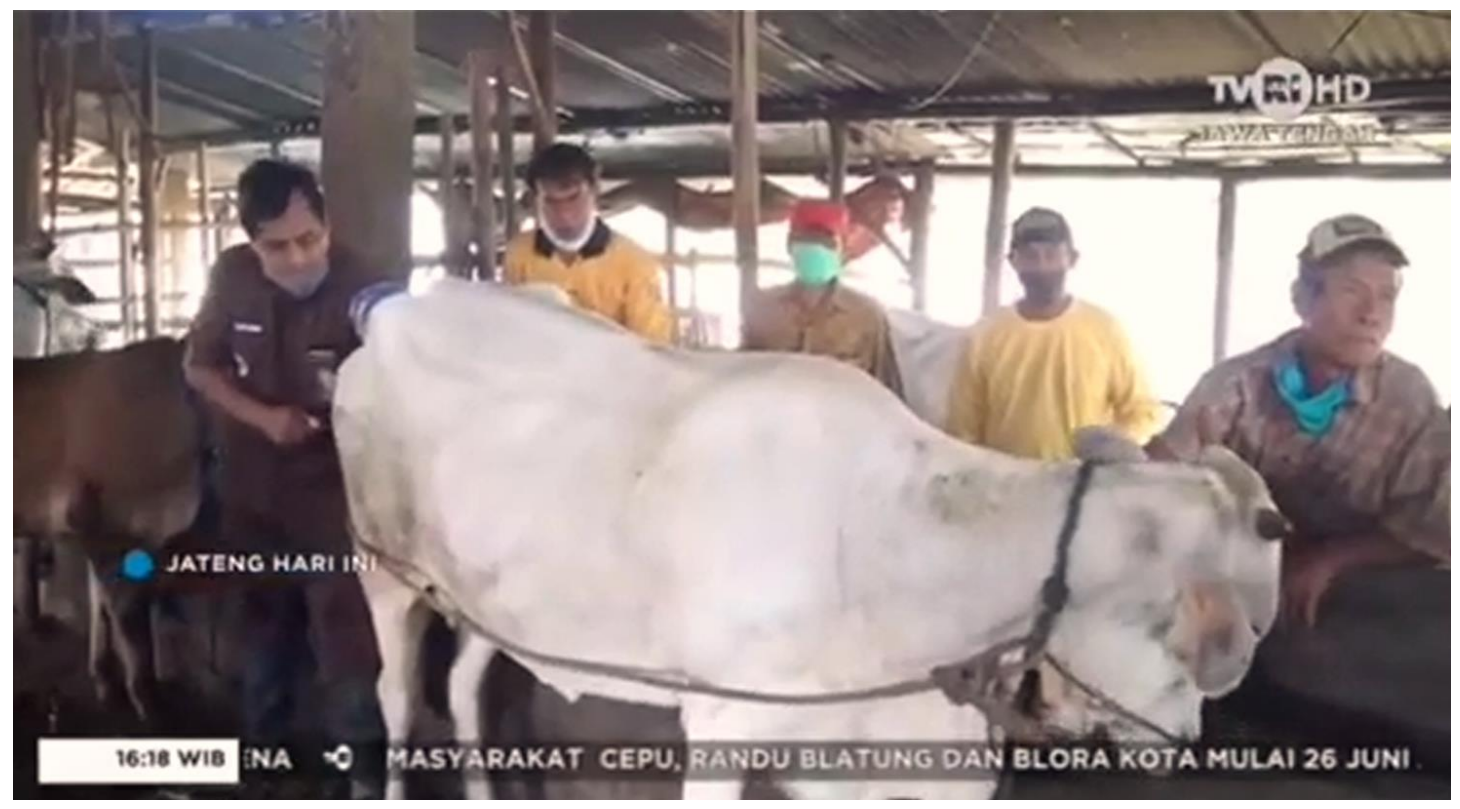

Gambar 2. Peternak sapi diajak praktek langsung mendeteksi sapi siap bunting dan cara melakukan inseminasi buatan

periode birahi yang berbeda memiliki prosentase bunting yang berbeda pula. Pada permulaan birahi kemungkinan bunting $44 \%$, di pertengahan birahi memiliki kemungkinan terbesar 82\%, akhir birahi karena gesekan akibat dinaiki oleh betina yang lain. Gambar 2 menunjukkan kegiatan praktek mendeteksi sapi siap bunting dan cara melakukan inseminasi buatan. 
Pertama, semen dari sapi pejantan ditampung dalam suatu alat seperti vagina buatan. Kualitas semen dievaluasi menurut gerakan massa, motilitas, LD dan konsentrasinya (Saputra dkk., 2017; Solihati dkk., 2019; Prastowo dkk., 2018). Hanya yang kualitas baik yang dapat diproses lebih lanjut untuk diencerkan dan dibekukan. Semen beku kemudian disimpan pada container berisi nitrogen cair dengan suhu $196^{\circ} \mathrm{C}$. Sebelum melaksanakan prosedur IB maka semen harus dicairkan (thawing) terlebih dahulu dengan mengeluarkan semen beku dari nitrogen cair dan memasukkannya dalam air hangat atau meletakkannya di bawah air yang mengalir. Suhu untuk thawing yang baik adalah $37^{\circ} \mathrm{C}$, jadi semen/straw tersebut dimasukkan dalam air dengan suhu badan $37^{\circ} \mathrm{C}$, selama 7-18 detik (Wuandari \& Prihatno, 2014). Setelah di thawing, straw dikeluarkan dari air kemudian dikeringkan dengan tissue. Kemudian straw dimasukkan dalam gun, dan ujung yang mencuat dipotong dengan menggunakan gunting bersih. Setelah itu plastik sheath dimasukkan pada gun yang sudah berisi semen beku/straw, sapi dipersiapkan, ekor diikat. Petugas IB memakai sarung tangan (glove) pada tangan yang akan dimasukkan ke dalam rectum. Tangan petugas IB dimasukkan ke rektum, hingga dapat menjangkau dan memegang leher rahim (servix), apabila dalam rektum banyak kotoran harus dikeluarkan lebih dahulu. Semen disuntikkan/ disemprotkan pada badan uterus yaitu pada daerah yang disebut dengan 'posisi ke empat' (Dana dkk., 2017). Setelah semua prosedur tersebut dilaksanakan maka gun dikeluarkan dari uterus dan servix dengan perlahanlahan.

\section{Digester pengolah limbah ternak sapi menjadi biogas dan pupuk organik}

Kotoran sapi merupakan limbah dari pencernaan yang dapat digunakan untuk menunjang pendapatan peternak. Peternak bisa memanfaatkan kotoran sapi menjadi biogas dan pupuk organik untuk menambah nilai ekonomi. Biogas adalah gas yang dihasilkan oleh aktifitas anaerobik atau fermentasi dari bahan -bahan organik termasuk diantaranya: kotoran manusia dan hewan, limbah domestik (rumah tangga), sampah biodegradable atau setiap limbah organik yang biodegradable dalam kondisi anaerobic (Abubakar \& Ismail, 2012). Biogas dapat digunakan sebagai bahan bakar kendaraan maupun untuk menghasilkan listrik. Biogas diolah kembali menjadi bahan bakar minyak yang lebih spesifik. Kandungan utama dalam biogas adalah metana dan karbon dioksida. Biogas dihasilkan dengan bantuan bakteri metanogen atau metanogenik. Bakteri ini secara alami terdapat dalam limbah yang 
mengandung bahan organik, seperti limbah ternak dan sampah organik. Umumnya, biogas diproduksi menggunakan alat yang disebut reaktor biogas (digester) yang dirancang agar kedap udara (anaerobik), sehingga proses penguraian oleh mikroorganisme dapat berjalan secara optimal. Prinsip pembuatan biogas adalah adanya dekomposisi bahan organik secara anaerobik (tertutup dari udara bebas) untuk menghasilkan gas yang sebagian besar adalah berupa gas metan (yang memiliki sifat mudah terbakar) dan karbon dioksida, gas inilah yang disebut biogas. Proses dekomposisi anaerobik dibantu oleh sejumlah mikroorganisme, terutama bakteri metan. Suhu yang baik untuk proses fermentasi adalah $30-55^{\circ} \mathrm{C}$ (Zielińska dkk., 2013; Xu dkk 2020), dimana pada suhu tersebut mikroorganisme mampu merombak bahan bahan organik secara optimal.

Bangunan utama dari instalasi reaktor biogas adalah digester yang berfungsi untuk menampung gas metan hasil perombakan bahan bahan organik oleh bakteri. Jenis digester yang digunakan adalah model continuous feeding, model yang paling banyak digunakan, dimana pengisian bahan organiknya dilakukan secara kontinu setiap hari (Mulyati, 2009; Putra dkk., 2017; Renilaili, 2015). Digester dibangun pada lahan yang berukuran sekitar $9 \mathrm{~m}^{2}$ dengan kapasitas $13 \mathrm{~m}^{3}$ untuk menghasilkan 5 titik kompor. Bahan bangunan yang dgunakan untuk membuat digester seperti pasir, semen, batu kali, batu koral, bata merah, besi konstruksi, cat dan pipa pralon. Lokasi yang dibangun dekat dengan kandang sehingga kotoran ternak dapat langsung disalurkan kedalam digester. Disamping digester dibangun juga penampung sludge (lumpur) dimana slugde tersebut nantinya dapat dipisahkan dan dijadikan pupuk organik padat dan cair. Gambar 3 menunjukkan skema ilustrasi digester yang dibangun di Desa Kuripan. 


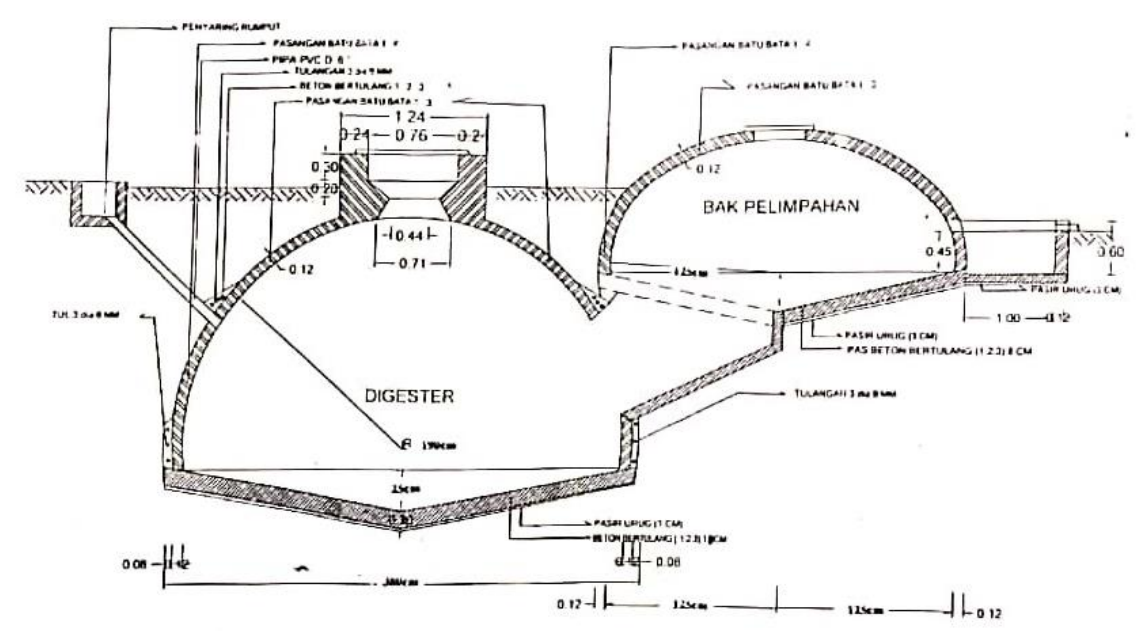

Gambar 3. Skema ilustrasi digester model continuous feeding yang dibangun pada lahan berukUran 9 $\mathrm{m}^{2}$ dengan kapasitas $13 \mathrm{~m}^{3}$ untuk menghasilkan 5 titik kompor.

\section{SIMPULAN}

Kegiatan diseminasi teknologi tepat guna telah dilaksanakan di Desa Kuripan, Kecamatan Karangawen Kabupaten Demak Jawa Tengah. Untuk membantu meningkatkan pendapatan warga, inovasi di sector peternakan sapi dilakukan dengan penerapan inseminasi buatan berbasis semen beku sexing-sperm dan digester pengolah limbah ternak menjadi biogas dan pupuk organik. Dengan metode community development, peran aktif warga menjadi tolok ukur keberhasilan kegiatan ini. Selain pemenuhan gizi sapi, faktor utama keberhasilan inseminasi buatan adalah kecermatan dalam mendeteksi birahi. Sedangkan untuk pengolahan limbah ternak sapi menjadi bogas dan pupuk organik, factor utama penentu keberhasilannya adalah kostruksi digester. Selain itu teknik pengumpulan (collections), pengangkutan (transport), pemisahan (separation) dan penyimpanan (storage) atau pembuangan (disposal) menjadi hal yang tidak boleh diabaikan. Melalui kegiatan ini, peternak sapi di Desa Kuripan, Kecamatan Karangawen Kabupaten Demak semakin memahami dasar-dasar inseminasi dan pembuatan biogas.

\section{SARAN}

Adapun saran pada program kemitraan masyarakat ini adalah: (1) kelompok tani memantau hasil inseminasi buatan dan melakukannya kembali, (2) menjaga dan merawat instalasi biogas, (3) Oleh sebab itu, warga diharapkan dapat terus menggunakan teknik yang diajarkan untuk meningkatkan kesejahterannya. 


\section{UCAPAN TERIMA KASIH}

Kegiatan diseminasi teknologi tepat guna ini didanai oleh Kementerian Riset dan Teknologi/Badan Riset dan Inovasi Nasional (Kemenristek/BRIN) Republik Indonesia tahun 2020. Terimakasih atas dukungan dari pemerintah dan segenap warga Desa Kuripan, Kecamatan Karangawen Kabupaten Demak Jawa Tengah yang menjadi penentu terselenggaranya kegiatan ini.

\section{DAFTAR PUSTAKA}

Abubakar, B. S. U. I., \& Ismail, N. (2012). Anaerobic digestion of cow dung for biogas production. ARPN journal of engineering and applied sciences, 7(2), 169-172.

Dana, W. D., Hamdan, B. P., Riady, G., Wahyuni, S., \& Iskandar, C. D. (2017). Pengaruh Deposisi Semen Saat Inseminasi Buatan Terhadap Angka Kebuntingan Sapi. ETD Unsyiah.

Kusumawati, E. D., Rahadi, S., Sudianata, F., \& Yulianti, D. L. (2018). Pengaruh Ketepatan Waktu Inseminasi Buatan Terhadap Tingkat Keberhasilan Kebuntingan Di Kecamatan Gedangan Kabupaten Malang Jawa Timur. Jurnal Ilmu dan Teknologi Peternakan Tropis, 5(2), 58-62.

Phillips, R., \& Pittman, R. (Eds.). (2014).
An Introduction to Community Development. London: Routledge.

Prastowo, Sigit, Pipin Dharmawan, Tristianto Nugroho, Aris Bachtiar, and Ahmad Pramono. "Kualitas semen segar sapi Bali (Bos javanicus) pada kelompok umur yang berbeda." Jurnal Ilmu Ternak Universitas Padjadjaran 18, no. 1 (2018): 1-7.

Putra, G. M. D., Abdullah, S. H., Priyati, A., Setiawati, D. A., \& Muttalib, S. A. (2017). Rancang Bangun Reaktor Biogas Tipe Portable dari Limbah Kotoran Ternak Sapi. Jurnal Ilmiah Rekayasa Pertanian dan Biosistem, 5, 369-374.

Renilaili, R. (2015). Analisa Hasil Biogas Dari Fesses Sapi Dengan Menggunakan 3 Macam Reaktor. Jurnal Tekno, 12(2), 33-42.

Salisbury, G. W., Vandemark, N. L., \& Lodge, J. R. (1978). Physiology of Reproduction and Artificial Insemination of Cattle (No. Ed. 2). New York: Wh Freeman and Company.

Saputra, D. J., Ihsan, M. N., \& Isnaini, N. (2017). Korelasi antara lingkar skrotum dengan volume semen, konsentrasi dan motilitas spermatozoa pejantan Sapi Bali. TERNAK TROPIKA Journal of Tropical Animal Production, 18(2), 59- 
68.

Solihati, N., Rasad, S. D., Yusrina, A., \& Winangun, K. (2019). Quality and Longevity of Local Ram's Sexed Sperm with Albumin Colum. Jurnal Ilmu Ternak Universitas Padjadjaran, 19(2), 29-37.

Susilawati, T. (2013). Pedoman Inseminasi Buatan Pada Ternak. Malang: Universitas Brawijaya Press.

Wulandari, I., \& Prihatno, S. A. (2014). Pengaruh Berbagai Temperatur Thawing Semen Beku Terhadap Keberhasilan Inseminasi Buatan Pada Sapi Potong. Jurnal Sain Veteriner FKH UGM, 32(1), 40-45.

Xu, J., Bu, F., Zhu, W., Luo, G., \& Xie, L. (2020). Microbial Consortiums of Hydrogenotrophic Methanogenic Mixed Cultures in Lab-Scale Ex-Situ Biogas Upgrading Systems under Different Conditions of Temperature, $\mathrm{pH}$ and CO. Microorganisms, 8(5), 772.

Zielińska, M., Cydzik-Kwiatkowska, A., Zieliński, M., \& Dębowski, M. (2013). Impact of temperature, microwave radiation and organic loading rate on methanogenic community and biogas production during fermentation of dairy wastewater. Bioresource technology, 129, 308-314. 